\title{
PENERAPAN COGNITIVE BEHAVIOR THERAPY DALAM PENGURANGAN PROKRASTINASI AKADEMIK MAHASISWA
}

\section{Pramitha Aulia, Achmad Gimmy Prathama dan Tutty I Sodjakusumah}

Fakultas Teknik Elektro, Universitas Telkom; Fakultas Psikologi, Universitas Padjadjaran E-mail:mithpsy@gmail.com,ahmad.gimmy@unpad.ac.id,t.sodjakusumah@unpad.ac.id

\begin{abstract}
This study aimed to test the application of Cognitive Behavior Therapy (CBT) in decreasing academic procrastination of college student. The experiment design was quasi-experimental pretest-posttest design. The effect of CBT in decreasing academic procrastination of college student was analyzed by comparing pretest and posttest results by Wilcoxon test. In the other hand, the qualitative data were collected by interview and analyzed by content analysis. The results was Cognitive Behavior Therapy (CBT) was able to improve the unhelpful rules that can lower academic procrastination behavior.
\end{abstract}

Key words: Academic Procrastination, college student, and Cognitive Behavior Therapy.

\begin{abstract}
Abstrak
Penelitian ini bertujuan untuk mengetahui apakah penerapan Cognitive Behavior Therapy (CBT) dapat menurunkan perilaku prokrastinasi akademik pada mahasiswa. Desain penelitian yang digunakan adalah quasi experimental, dengan pretest-posttest design. Data diperoleh dari hasil kuesioner dan juga hasil interview. Data kuantitatif hasil kuesioner dianalisa dengan teknik statistik non-parametrik, yaitu menggunakan pengujian Wilcoxon, sedangkan data kualitatif hasil wawancara dianalisis dengan content analysis. Berdasarkan hasil pengujian Wilcoxon, dapat disimpulkan bahwa Cognitive Behavior Therapy (CBT) dapat memperbaiki unhelpful rules mahasiswa sehingga dapat menurunkan perilaku prokrastinasi akademik pada mahasiswa Fakultas Psikologi Universitas Padjadjaran"
\end{abstract}

Kata kunci: Cognitive Behavior Therapy, prokrastinasi akademik, mahasiswa

\section{PENDAHULUAN}

Prokrastinasi secara umum diartikan sebagai kemalasan oleh kebanyakan orang. Dalam bahasa sehari-hari, orang menyebutnya menunda, meninggalkan, mengabaikan dan lain-lain. Menurut Saulsman (2008) prokrastinasi adalah: "making a decision for no valid reason to delay or not complete a task or goal you"ve commited too, and instead doing something of lesser importance, despite there being negative consequences through on the original task or goal." 
Berdasarkan studi dan penelitian yang dilakukan oleh Saulsman (2008), latar belakang seseorang melakukan prokrastinasi adalah dikarenakan adanya keyakinan dan asumsi yang salah atau unhelpful rules yang dimiliki oleh individu. Unhelpful rules merupakan bagian dari intermediate belief yang merupakan suatu aturan hidup yang ada dalam diri individu. Intermediate belief terdiri dari sikap, rules dan asumsi. Intermediate belief juga merupakan keyakinan yang tertanam dalam diri seorang individu dan cenderung menetap. Beberapa individu merasa bersalah dan mencari alasan-alasan yang masuk akal untuk mendapatkan pembenaran.

Menurut Saulsman (2008) untuk mencegah terjadinya rasa bersalah yang besar ketika melakukan prokrastinasi, individu biasanya membuat alasan-alasan yang umum dan kedengaran masuk akal sehingga memiliki pembenaran dan merasa wajar dengan prokrastinasi yang dilakukan. Alasan tersebut dapat berupa hal-hal yang memungkinkan dan sesuai dengan kondisi yang dihadapi pada saat penyelesaian tugas misalnya kelelahan, tidak dalam keadaan mood, masih memiliki banyak waktu, belum memiliki persiapan yang cukup, kurang menguasai materi tugas dan lain-lain.

Terdapat beberapa penelitian yang dilakukan oleh salah satu pusat terapi yaitu Cognitive Therapy Centre of Long Island, yang menyatakan bahwa CBT telah terbukti mampu mengubah berbagai jenis permasalahan dan salah satu diantaranya adalah masalah prokrastinasi dan hingga saat ini pusat terapi tersebut menyediakan CBT bagi orang-orang yang memiliki masalah dengan prokrastinasi.

Atas dasar adanya fenomena-fenomena serta fakta di atas, diperoleh bahwa sebagian besar mahasiswa yang melakukan prokrastinasi cenderung memiliki unhelpful rules yang berasal dari persepsi dan asumsi yang salah mengenai kemampuan diri dan tugas yang sedang dihadapi. Sebagian besar dari mereka menganggap tugas sebagai suatu hal yang tidak menyenangkan dan memunculkan emosi yang juga tidak menyenangkan. Persepsi yang salah tersebut pada akhirnya menimbulkann suatu negative automatic thought yang akan selalu mempengaruhi emosi dan perilaku yang dimunculkan. Dan sebagai hasilnya, mereka cenderung melakukan penghindaran terhadap tugas akademik yang ada. Oleh karena itu, peneliti tertarik untuk melakukan penerapan CBT terhadap mahasiswa yang melakukan prorastinasi akademik untuk mengubah pemikiran mereka yang salah dan irasional dalam memandang dan memaknai kemampuan dirinya serta tugas yang sedang dihadapinya.

Tujuan akhir dari terapi ini adalah mengidentifikasi negative automatic thought yang berasal dari unhelpful rules yang dimiliki oleh mahasiswa yang melakukan prokrastinasi dan kemudian menggantinya dengan pemikiran yang lebih adaptif. Setelah cara berpikir yang adaptif tersebut cukup berkembang, perubahan dalam emosi dan perilaku juga akan terpengaruh (Wojtyna, E, dkk, 2007). Pertanyaan penelitian yang diajukan dalam penelitian ini adalah apakah CBT dapat mempengaruhi penurunan prokrastinasi pada mahasiswa. 


\section{METODE}

Desain penelitian yang digunakan adalah quasi eksperimental, yaitu desain penelitian yang menerapkan prosedur eksperimental tetapi tidak semua variabel extraneous dapat dikontrol (Christensen, 1988). Berdasarkan pada permasalahan penelitian, desain kuasi eksperimen yang digunakan adalah One-Group PretestPosttest Design. Kerlinger (2000) menyatakan bahwa ciri utama dari bentuk penelitian ini adalah bahwa suatu kelompok dibandingkan dengan dirinya sendiri. Prosedur dari rancangan ini kemudian dijelaskan lebih jauh oleh Kerlinger (2000) sebagai berikut: Suatu kelompok di ukur sehubungan dengan variabel dependen, Y, sebelum pelaksanaan perlakuan (manipulasi eksperimental) atau biasa disebut pretes. Kemudian dilakukan manipulasi eksperimental (X) yang dirancang untuk mengubah variabel dependen itu. Setelah itu, variabel dependen dari para partisipan diukur lagi, $\mathrm{Y}_{2}$. Perbedaan skor antara $\mathrm{Y}_{1}$ dan $\mathrm{Y}_{2}$, diperiksa untuk menemukan perubahan yang terjadi. Christensen (2004) menyatakan bahwa pada $Y_{2}$ perlakuan telah usai dilakukan, atau dengan kata lain partisipan penelitian sudah tidak berada dalam proses perlakuan, sehingga partisipan seperti berada dalam keadaan awal (baseline) sebelum perlakuan diberlakukan.

\section{Partisipan Penelitian}

Partisipan dalam penelitian ini adalah mahasiswa dengan karakteristik: masih aktif mengikuti perkuliahan, memeiliki prokrastinasi taraf cenderung tinggi dan tinggi (diperoleh melalui pretes yang juga merupakan seleksi sampel), dan bersedia untuk berpartisipasi dalam kegiatan intervensi pada penelitian ini.

\section{Instrumen}

Kuesioner prokrastinasi akademik ini diisi dengan meminta responden untuk memilih salah satu di antara lima kemungkinan jawaban, yaitu Selalu (SL), Sering (SR), Kadang-kadang (KK), Jarang (JR), dan Tidak Pernah (TP). Pemilihan jawaban didasarkan pada kesesuaian pernyataan dengan perilaku responden dalam menjalankan tugas akademik sebagai mahasiswa.

Pada alat ukur prokrastinasi akademik dilakukan pengkategorisasian dengan metode distribusi frekuensi. Penyusunan tabel distribusi frekuensi dimaksudkan untuk lebih mempermudah pembahasan atas dasar hasil pengukuran yang dilakukan sekaligus untuk menentukan kedudukan partisipan dalam kelompok. Data yang diperoleh dari kuesioner Prokrastinasi Akademik akan dikelompokkan ke dalam empat kategori, yaitu rendah, cenderung rendah, cenderung tinggi dan tinggi dalam perilaku prokrastinasi akademiknya. 
Langkah berikutnya adalah menghitung skor total dimensi-dimensi variabel Prokrastinasi Akademik Mahasiswa. Dimensi-dimensi prokrastinasi akademik terdiri dari tugas menulis, tugas persiapan menghadapi ujian, tugas membaca, tugas administrasi, tugas menghadiri pertemuan, dan tugas akademik secara keseluruhan. Enam dimensi ini dibagi dalam empat kategori yaitu tinggi, cenderung tinggi, cenderung rendah dan rendah.

\section{Prosedur Pelaksanaan Penelitian}

Prosedur pelaksanaan dalam penelitian ini dilakukan dan disesuaikan dengan etika yang berlaku dalam profesi maupun bidang ilmu Psikologi dimana semua tahap yang bersangkutan dengan kesejahteraan partisipan penelitian dilakukan dengan sangat seksama dan atas supervisi dari pihak yang dianggap ahli dalam pemberian CBT. Prosedur penelitian dilakukan dengan mengikuti beberapa tahap, yang meliputi tahap persiapan, tahap pelaksanaan, dan tahap penyelesaian.

\section{HASIL}

\section{Profil Prokrastinasi}

Pada penelitian ini, peneliti mendapatkan 4 orang partisipan yang memenuhi kriteria partisipan penelitian, yaitu mahasiswa yang masih aktif dan memiliki perilaku prokrastinasi yang berada pada taraf cenderung tinggi sampai dengan tinggi. Adapun identitas dan gambaran umum dari keempat orang partisipan penelitian adalah sebagai berikut:

Partisipan 1 berjenis kelamin perempuan, berusia 19 tahun dan merupakan suku Cina. Saat penelitian dilakukan dia berada pada semester 1 dan aktif dalam organisasi keagamaan. Dia merasa sering melakukan prokrastinasi, diantaranya yang paling sering dilakukan adalah tugas membuat makalah. Dia memiliki banyak sebab mengapa melakukan prokrastinasi, diantaranya adalah merasa punya banyak waktu luang dan masih banyak yang lebih penting yang harus dikerjakan. Waktu luang lebih banyak dia gunakan untuk bermain game online, bermain dengan teman dan mengikuti kegiatan keagamaan. Pola atau kebiasaan prokrastinasi dalam mengerjakan tugasnya adalah mengerjakan tugas sebelum batas waktu. Dia merasakan prokrastinasinya sudah mengganggu dan ingin merubahnya serta sudah berusaha mengatasinya dengan membuat jadwal mingguan namun hanya bertahan dalam dua minggu. Dia kesulitan mengatasi prokrastinasinya karena merasa bermain game online lebih menyenangkan daripada mengerjakan tugas sehingga sering lupa waktu dan akhirnya pengerjaan tugas menjadi tertunda. Dampak dari prokrastinasi yang dia lakukan adalah banyak tugas yang menumpuk dan mengalami stres ketika berhadapan dengan batas waktu pengumpulan tugas. 
Partisipan 2 ini adalah mahasiswa perempuan dengan usia 20 dan sudah berada pada semester 5 dengan indeks prestasi kumulatif sebesar 3,04. Sekalipun tidak terlibat dalam kegiatan ekstra luar kampus, dia merasa banyak melakukan prokrastinasi dalam kegiatan perkuliahan. Tugas yang paling sering ditunda adalah menulis makalah. Penyebab dia menunda tugas adalah terlalu lelah, stres, tidak memiliki mood dalam mengerjakan tugas pada waktu tertentu. Pola prokrastinasi yang dia lakukan adalah mengerjakan tugas beberapa jam sebelum batas waktu tugas harus diselesaikan. Aktivitas prokrastinasinya adalah menonton televisi atau video, tidur, dan jalan-jalan bersama teman. Prokrastinasi yang dia lakukan sudah dia anggap mengganggu dirinya sehingga dia ingin melakukan perubahan atau menghilangkan prokrastinasinya. Dia sudah berusaha menguranginya dengan membuat jadwal mingguan namun hanya bertahan dalam waktu tiga minggu. Dalam usahanya untuk mengurangi prokrastinasinya dia merasa kesulitan. Kesulitan yang dialami adalah merasa tubuh sangat lelah dan harus istirahat sebentar namun seringkali istirahanya terlalu berlebihan atau terlalu lama sehingga waktu untuk mengerjakan tugas sudah habis. Akibat dari ketidakmampuannya untuk mengatasi prokrastinasinya dia merasa cemas dan tidak tenang karena tugas-tugas belum juga selesai dikerjakan dan sekalipun selesai dikerjakan maka tugasnya diselesaikan dengan kualitas yang buruk karena terburu-buru dalam melakukannya.

Partisipan 3 adalah mahasiswa perempuan yang berusia 21 tahun dan berada pada semester 5 dengan indeks prestasi kumulatif 3,21. Mahasiswa ini merasa sering melakukan prokrastinasi dalam kegiatan akademik. Tugas yang paling sering ditunda adalah tugas membuat makalah. Penundaan itu disebabkan karena ketidakyakinan akan kemampuannya dan keyakinannya akan muncul jika dia melihat dulu pekerjaan tugas temannya untuk memperoleh gambaran dalam mengerjakan tugas. Pola prokrastinasinya adalah mengerjakan tugas sehari sebelum batas waktu akhir pengerjaan. Aktivitas yang banyak dilakukan sehingga menjadi prokrastinator adalah bermaian dengan teman dan tidur. Prokrastinasi yang dia lakukan sudah dia rasakan mengganggu dirinya sehingga dia ingin melakukan porubahan agar tidak melakukan prokrastinasi lagi. Usaha yang dia lakukan untuk mengurangi prokrastinasinya adalah mencoba mengurangi penundaaan dan mengerjakan secara bertahap tugas-tugas yang mudah terlebih dahulu namun cara ini hanya berhasil pada tugas-tugas tertentu saja. Penyebab prokrastinasinya adalah kurang yakin dengan format tugas yang akan dibuat sehingga harus menunggu teman yang lain mengerjakan dan mencontohnya sehingga sangat tergantung dengan waktu teman mengerjakan tugas. Akibatnya dia merasa cemas dan tidak tenang karena tugas belum dikerjakan dan kualitas tugas menjadi buruk karena dikerjakan terburu-buru dan seadanya saja.

Partisipan 4 adalah mahasiswa perempuan dengan usia 21 tahun dan berada pada semester 7 dengan indeks prestasi kumulatif 2,63. Mahasiswa ini merasa sering melakukan prokrastinasi akademik terutama terhadap tugas menulis makalah. Sebab prokrastinasi yang dia lakukan adalah dia berfikir bahwa hidup ini hanya sekali 
sehingga harus dihabiskan dengan santai dan tidak terlalu memikirkan tugas. Selain itu menganggap bahwa tugas bisa dikerjakan beberapa jam sebelum dikumpulkan. Pola prokrastinasi akademik yang dilakukan adalah mengerjakan tugas beberapa jam sebelum batas waktu akhir pengerjaan. Aktivitas yang menyebabkan prokrastinasi adalah membaca novel, komik, dan jalan-jalan dengan teman. Sekalipun demikian dia ingin merubah prokrastinasinya karena dia merasa sudah menggangu. Dia pernah mencoba menguranginya dengan membuat jadwal harian dengan terperinci namun hanya bertahan sampai dua minggu. Kesulitannya dalam mengurangi prokrastinasinya adalah karena dia menganggap novel-novel baru yang dia baca lebih menarik daripada mengerjakan tugas sehingga membuatnya sering lupa waktu dan menomor duakan tugas dan akhirnya ditunda. Akibatnya tugas-tugas yang dia lakukan kualitasnya buruk karena dilakukan seadanya dan terburu-buru dan menyebabkannya kurang tidur dan tugasnya menumpuk.

Tabel 1

Skor Pretes dan Postes Prokrastinasi Berdasarkan Tugas

\begin{tabular}{ccccccccc}
\hline Keterangan & \multicolumn{2}{c}{ Partisipan 1 } & \multicolumn{2}{c}{ Partisipan 2 } & Partisipan 3 & \multicolumn{2}{c}{ Partisipan 4 } \\
\cline { 2 - 8 } & Pre & Post & Pre & Post & Pre & Post & Pre & Post \\
\hline Total & 171 & 144 & 167 & 107 & 173 & 96 & 166 & 109 \\
Tugas Menulis & 38 & 33 & 38 & 23 & 47 & 21 & 41 & 26 \\
Tugas Persiapan Ujian & 36 & 30 & 37 & 23 & 46 & 26 & 40 & 28 \\
Tugas Membaca & 19 & 19 & 22 & 15 & 27 & 18 & 23 & 21 \\
Tugas Administrasi & 13 & 14 & 19 & 14 & 8 & 6 & 13 & 7 \\
Tugas Menghadiri Pertemuan & 37 & 28 & 28 & 16 & 21 & 14 & 20 & 12 \\
Kinerja akademik Keseluruhan & 16 & 20 & 23 & 15 & 22 & 14 & 26 & 15 \\
\hline
\end{tabular}

\section{Analisis Efek Perlakuan}

Pembuktian terhadap hipotesis penelitian dilakukan melalui uji Wilcoxon. Dari hasil pengujian statistik diperoleh hasil nilai Z: -1,826 dengan nilai probabilitas 0,068 untuk uji 2 sisi atau 0,034 untuk uji satu sisi. Pada penelitian ini peneliti menggunakan uji satu sisi karena hipotesis dalam penelitian ini berarah. Dengan demikian, tampak bahwa nilai probabilitasnya lebih kecil dari 0,05 yang berarti ada perbedaan signifikan antara pretes dan postes.

Tabel 2

Hasil Uji Wilcoxon pada Keempat Domain

\begin{tabular}{lrrrrrr}
\hline \multicolumn{1}{c}{ Statistik } & \multicolumn{1}{c}{$\begin{array}{c}\text { Tugas } \\
\text { Menulis }\end{array}$} & $\begin{array}{c}\text { Persiapan } \\
\text { ujian }\end{array}$ & $\begin{array}{c}\text { Tugas } \\
\text { Membaca }\end{array}$ & $\begin{array}{c}\text { Tugas } \\
\text { Administratif }\end{array}$ & $\begin{array}{c}\text { Menghadiri } \\
\text { Pertemuan }\end{array}$ & $\begin{array}{c}\text { Akademik } \\
\text { Keseluruhan }\end{array}$ \\
\hline Z & -1.826 & -1.826 & -1.890 & -0.378 & -1.461 & -1.826 \\
$\begin{array}{l}\text { Asymp. Sig. } \\
\text { (2-tailed) }\end{array}$ & .068 & .068 & .059 & .705 & .144 & .068 \\
\hline
\end{tabular}


Berdasarkan perhitungan pada tabel di atas, untuk tugas menulis makalah diperoleh nilai $Z=1,826$ dengan nilai probabilitas 0,068 untuk uji 2 sisi atau 0,034 untuk uji satu sisi. Pada tugas persiapan ujian diperoleh nilai $\mathrm{Z}=1,826$ dengan nilai probabilitas sebesar 0,068 untuk uji 2 sisi atau 0,034 untuk uji satu sisi. Begitu juga pada tugas membaca $Z=1,890$ dengan nilai probabilitas sebesar 0,059 untuk uji 2 sisi dan 0,0295 untuk uji satu sisi. Sedangkan pada tugas administratif, nilai $Z=0,378$ dengan nilai probabilitas sebesar 0,705 untuk uji 2 sisi dan 0,3525 untuk uji satu sisi. Dan pada tugas menghadiri pertemuan, nilai $\mathrm{Z}=1,461$ dengan nilai probabilitas sebesar 0,144 untuk uji 2 sisi dan 0,072 untuk uji satu sisi. Terakhir pada kinerja akademik keseluruhan) $\mathrm{Z}=1,826$ dengan nilai probabilitas sebesar 0,068 untuk uji 2 sisi dan 0,034 untuk uji satu sisi. Dari nilai tersebut, tampak bahwa nilai probabilitas dari tugas menulis, persiapan ujian, tugas membaca dan kinerja akademik keseluruhan $<0,05$ yang berarti dapat dikatakan bahwa terdapat perbedaan yang signifikan antara pretes dan postes. Sementara itu, tugas administratif dan menghadiri pertemuan memiliki nilai probabilitasnya > 0,05 yang berarti dapat dikatakan bahwa tidak terdapat perbedaan yang signifikan antara pretes dan postes. Dengan demikian, dapat disimpulkan bahwa pemberian CBT pada keempat partisipan berpengaruh terhadap penurunan dimensi prokrastinasi tugas menulis, persiapan menghadiri pertemuan, tugas membaca dan kinerja akademik keseluruhan.

\section{PEMBAHASAN}

Analisa hasil perolehan data dalam penelitian ini dilakukan dengan menggunakan analisa deskriptif yaitu berdasarkan perbandingan antara nilai pretes dan postes masing-masing partisipan dalam penelitian. Berdasarkan hasil perbandingan data tersebut, diperoleh bahwa terdapat penurunan skor pada semua partisipan setelah diberikan treatmen (CBT). Penurunan skor tidak hanya terjadi pada skor total, tetapi juga pada setiap dimensi tugas yang terdiri dari 6 area tugas akademik. Perubahan skor yang terjadi mencapai 74 poin. Dengan demikian, dapat dikatakan bahwa intervensi yang diberikan yaitu berupa Cognitive Behavior Therapy (CBT) dapat menurunkan perilaku prokrastinasi akademik pada 6 area akademik sekaipun hanya empat area yang signifikan.

Hasil perolehan ini sesuai dengan penelitian yang dilakukan oleh Wright (2006) yang menyatakan bahwa CBT merupakan salah satu terapi yang sangat efektif untuk mengurangi perilaku prokrastinasi karena membantu seseorang untuk mengubah pikiran yang salah mengenai tugas yang dihadapinya dan tentu saja mengenai dirinya sendiri.

Dari data yang diperoleh dari hasil kuesioner dan interview, dapat dilihat bahwa perilaku prokrastinasi yang dilakukan oleh para partisipan disebabkan oleh adanya unhelpful rules yaitu pleasure seeking pada partisipan 1 dan 4, fear of failure or 
dissaproval pada partisipan 3, dan depleted energy pada partisipan 2. Unhelpful rules ini muncul dalam bentuk negative automatic thought (NAT) yang secara otomatis akan aktif ketika dihadapkan pada tugas yang dinggap tidak menyenangkan oleh partisipan. Dari hasil perolehan data, didapatkan bahwa tugas yang paling banyak mengalami prokrastinasi akademik adalah tugas menulis makalah. Skor pada dimensi tugas ini merupakan skor yang paling tinggi pada semua partisipan. Hal ini menunjukkan bahwa, tugas akademik menulis makalah, baik pribadi maupun kelompok merupakan tugas akademik yang paling tidak menyenangkan dan mampu menimbulkan NAT. Ketikan NAT aktif, biasanya diikuti oleh rasa tidak nyaman seperti cemas, kesal, malas dan perasaan tidak menyenangkan lainnya. Untuk menghindari rasa tidak nyaman ini, keempat partisipan memunculkan alasan-alasan untuk melakukan prokrastinasi seperti masih banyak waktu, teman yang lain juga belum selesai dan tugas ini tidak terlalu penting. Pada akhirnya menimbulkan aktivitas prokrastinasi berupa bermain games, membaca novel, tidur, jalan-jalan dengan teman dsb. Proses ini menimbulkan konsekuensi positif yaitu hilangnya rasa tidak nyaman yang ditimbulkan oleh tugas dan konsekuensi negatif berupa tugas yang menumpuk, nilai yang buruk dan merasa bersalah karena tidak menyelesaikan tugas. Akhirnya proses ini menjadi suatu siklus yang dinamakan siklus prokrastinasi.

Berdasarkan hasil penelitian ini, CBT mampu memutuskan siklus prokrastinasi akademik ini atau dengan kata lain mengurangi perilaku prokrastinasi akademik ini dengan mengubah NAT menjadi pikiran yang lebih realistis sehingga akan membentuk rules baru yang lebih adaptif. Dengan mengacu pada teori dari Beck (1995), Moorey \& Greer (2002), untuk dapat merubah perilaku prokrastinasi akademik maka dalam penelitian ini CBT dilakukan sebanyak tujuh pertemuan. Pertemuan pertama untuk melakukan psikoedukasi mengenai CBT dan siklus prokrastinasi serta memberikan lembar kerja berupa identifikasi unhelpful rules dimana partisipan diminta untuk mengidentifikasikan NAT dan unhelpful rules yang muncul ketika dihadapkan pada tugas akademik tertentu serta dampaknya terhadap reaksi emosi dan perilaku. Pertemuan kedua s/d keempat dilakukan untuk mengubah cara berpikir partisipan, mengenali rasa tidak nyaman, mengidentifikasi siklus prokrastinasi akademik yang terjadi dan membuat suatu action plan berdasarkan pemahamannya terhadap hal-hal yang perlu diubah untuk memperoleh suatu penurunan perilaku prokrastinasi akademik. Adapun pertemuan kelima dan keenam adalah untuk melakukan evaluasi terhadap action plan yang terlah dijalankan agar dapat melakukan revisi terhadap strategi-strategi yang masih belum sempurna dalam proses perubahan. Pertemuan ketujuh adalah terminasi dimana terapis memotivasi partisipan untuk dapat menjadi terapis bagi dirinya sendiri dan mendorong untuk tetap melakukan perubahan secara konsisten dengan memantau seluruh pikiran yang muncul ketika dihadapkan pada tugas di masa yang akan datang.

Selama proses terapi berlangsung, para partisipan mulai menyadari bahwa perilaku prokrastinasi yang mereka lakukan selama ini adalah hasil dari NAT dan 
unhelpful rules yang tertanam dalam diri mereka. Kemudian secara perlahan mulai bisa mengubah pikiran negatif tersebut dan menggantinya dengan pikiran baru yang lebih realistis. Pada awalnya partisipan merasa tidak mudah untuk mengganti pikiran lama dengan pikiran baru yang lebih realistis, namun setelah partisipan menuliskan konsekuensi dari pikiran-pikiran negatif yang sebagian besar merugikan maka keempat partisipan berusaha keras untuk mengganti pikirannya dengan yang baru dan lebih realistis.

Keberhasilan empat partisipan dalam mengubah unhelpful rules menjadi rules yang lebih realistis adalah dikarenakan adanya kesadaran akan banyaknya kerugian yang dihasilkan dari NAT yang berasal dari unhelpful rules yang selama ini tertanam dalam diri mereka. Partisipan 1 merasakan kerugian berupa tugas yang menumpuk, merasa cemas dan stres ketika harus mengerjakan tugas yang belum terselesaikan, hasil pekerjaan yang tidak maksimal karena dikerjakan seadanya saja. Demikian halnya dengan partisipan 2 dan 4 yang merasakan hal yang sama. Hal itu diperparah dengan nilai akademik yang buruk karena hasil kerja yang tidak maksimal serta munculnya perasaan bersalah ketika sedang bermain dengan teman-teman padahal tugas belum selesai. Begitu juga yang dirasakan oleh partisipan 3 yang merasa stres karena dikejar batas akhir tugas dan memperoleh nilai buruk. Kerugian ini membuat empat partisipan melakukan pertimbangan untuk mengubah pikiran negatif menjadi pikiran yang lebih realistis.

Berdasarkan hasil pengolahan data, dapat diambil kesimpulan: pemberian terapi CBT mampu menurunkan perilaku prokrastinasi akademik pada mahasiswa yang berada pada taraf perilaku prokrastinasi yang cenderung tinggi. Adanya unhelpful rules pada mahasiswa menyebabkan mahasiswa melakukan penilaian yang salah terhadap tugas akademik yang dihadapi dan terhadap diri sendiri dalam proses penyelesaian tugas akademik sehingga menimbulkan rasa tidak nyaman yang cenderung dihindari oleh mahasiswa tersebut. Penghindaran rasa tidak nyaman tersebut menyebabkan mahasiswa melakukan perilaku prokrastinasi untuk menurunkan dan menghilangkan rasa tidak nyaman.

Terapi CBT mampu dalam menurunkan perilaku prokrastinasi akademik pada empat area akademik yaitu tugas membuat tulisan, persiapan menghadapi ujian, tugas membaca dan kinerja akademik secara keseluruhan, tetapi tidak mampu menurunkan perilaku prokrastinasi dalam area akademik tugas administratif dan menghadiri pertemuan.

Dengan Cognitive Behavior Therapy, semua responden memahami bagaimana cara untuk mengubah pikiran negatif ketika mereka menghadapi situasi yang menekan. Efektivitas CBT juga dipengaruhi oleh motivasi, perhatian (atensi), dan juga keaktifan partisipan selama mengikuti proses terapi, sehingga membuat mereka lebih cepat dalam mendapatkan insight mengenai materi ataupun kondisi yang terjadi padanya. Faktor yang mempengaruhi efektifitas CBT selanjutnya adalah kerajinan partisipan dalam mengerjakan tugas rumahnya, sehingga dapat membiasakan 
partisipan untuk berpikir lebih positif dan realistis. Selain faktor-faktor tersebut, faktor kognitif juga dapat menunjang proses pemahaman partisipan.

Dalam penelitian ini, CBT memiliki efektifitas yang paling rendah pada partisipan mahasiswa baru dikarenakan proses adaptasi lingkungan yang sedang dijalaninya dalam proses belajar di perguruan tinggi.

\section{DAFTAR PUSTAKA}

Akinsola, M.K, et.al. 2007. Correlates of Academic procrastination and mathematics Achievement of University Undergraduate Students. Eurasia Journal of Mathematics, Science \& Technology Education.

Beck, Judith S. (1995). Cognitive Therapy: Basics and beyond. New York: the Guilford Press.

Beswick, G. (1988). Psychological Antecendents of Student Procrastination. Australia: Australian Psychologist.

Bond, F.W. \& Dryden, W. (2001). Handbook of Brief Cognitive Behavior Therapy. England: John Wiley \& Sons Ltd.

Christensen, L., B. (1997). Experimental Methodology. Allyn and Bacon.

Curwen, B., Palmer, S., Ruddell, P. (2000). Brief Cognitive Behavior Therapy. London: Sage Publications.

Faturrahman, R. (2008). Studi Mengenai Intensi Perilaku Prokrastinasi Akademik pada Mahasiswa Fakultas Psikologi Universitas Padjadjaran dalam Menyelesaikan Tugas Akademik. Sumedang. Universitas Padjadjaran. (Tidak dipublikasikan).

Ferrari, J.R., McCown, W., \& Johnson, J. Procrastination and Task Avoidance: Theory, Research, and Perlakuan. New York: Plenum Press.

Fibrianti, I., D., 2009. Hubungan Antara Dukungan Sosial Orang Tua dengan Prokrastinasi Akademik dalam Menyelesaikan Skripsi pada Mahasiswa Fakultas Psikologi Universitas Diponegoro Semarang. Fakultas psikologi Universitas Diponegoro.

Graziano, A.M. \& Raulin, M. (2000). Research Methods: A Process of Inquiry, 4th edition. Boston, USA: Allyn \& Bacon.

Green. (1982). Minority Students, Self Control of Procrastination. Journal of Counseling Psychology. 
Gufron, M.N. 2003. Hubungan kontrol Diri dan Persepsi Remaja terhadap penerapan Disiplin Orang Tua dengan Prokrastinasi Akademik. Yogyakarta: Program Pasca Sarjana Universitas Gajah Mada. Diakses dari http://damandiri.or.id

Hadi, S. (2004). Metodologi Research jilid 2. Yogyakarta: Andi Offset

Hermawan, H. (2010). Hubungan Strategi Regulasi Emosi Dengan Prokrastinasi Akademik Pada Mahasiswa. Suatu Studi Mengenai Hubungan Penggunaan Starategi Regulasi Emosi Secara Kognitif dengan Perilaku Prokrastinasi Akademik pada Mahasiswa dalam Menyelesaikan Tugas Akademik di Fakultas Psikologi Universitas Padjadjaran. Skripsi Tidak Dipublikasikan.

Kerlinger, F., N. (2004). Asas-asas Penelitian Behavioral. Gajah Mada University Press.

Latipun. (2006). Psikologi Eksperimen (5th ed.). Malang: UMM Press

Lazarus, R.S. (1966) Psychological Stress and the Coping Process. Newyork: McGraw-Hill 